\title{
Divergent effects of container port choice incentives on users' behavior
}

\author{
R.B. Castelein ${ }^{\mathrm{a}, \mathrm{d}, *}$, H. Geerlings ${ }^{\mathrm{a}, \mathrm{d}}$, J.H.R. van Duin ${ }^{\mathrm{b}, \mathrm{c}, \mathrm{d}}$ \\ ${ }^{a}$ Department of Public Administration and Sociology, Erasmus University Rotterdam, Burgemeester Oudlaan 50, 3062PA, Rotterdam, the Netherlands \\ ${ }^{\mathrm{b}}$ Faculty of Policy, Technology, and Management, Delft University of Technology, Jaffalaan 5, 2628BX, Delft, the Netherlands \\ ${ }^{\mathrm{c}}$ Research Centre for Sustainable Port Cities, Rotterdam University of Applied Sciences, Heijplaatstraat 23, 3089JB, Rotterdam, the Netherlands \\ ${ }^{\mathrm{d}}$ Project EURECA (Effective Use of Reefer Containers Through the Port of Rotterdam - a Transition Oriented Approach), the Netherlands
}

\section{A R T I C L E I N F O}

\section{Keywords:}

Container ports

Port competition

Port choice

Port competitiveness

\begin{abstract}
A B S T R A C T
Port choice decisions are often considered to be based on unambiguous choice criteria. The authors examine how port users' evaluation of these criteria can differ and how this may affect actors' incentive structure and decision making, and ultimately port performance. Apart from ports' physical characteristics, the paper considers port policy and freight market conditions as components of actors' incentive structures. As port users interact, each actor's decision making has consequences for the incentives offered to others - with an important role for strategic behavior. The aggregate of port users' decisions affects a port's throughput, cargo composition, and value added, and has implications for handling efficiency. This paper combines these insights within an overarching framework linking port characteristics, policy, and freight market conditions to port user choice behavior and the consequences for ports.

The paper explores various facets of this framework using the case of how the Port of Rotterdam competes along the Hamburg-Le Havre range, drawing on port throughput data on various levels of detail and in-depth interviews with a representative selection of port stakeholders. It shows that there is a downside to ports being particularly attractive to carriers, in that the port that offers the most incentives to carriers disproportionately attracts relatively low-value activities: inefficient calls and a large share of empty containers, along with a strong import/export imbalance. Interview findings contextualize the findings from the data and elaborate further on the mechanisms underpinning these observations. Most importantly, the attractiveness of a port for carriers does not always translate into attractiveness for shippers. The challenge for port policy is to balance the port's positioning toward its different categories of users and achieve a congruent value proposition for all port users.
\end{abstract}

\section{Introduction}

Port competitiveness is generally conceptualized as driven by straightforward and unambiguous criteria, such as port costs, handling efficiency, geographical location, hinterland connectivity, and the quality of infrastructure and services, that draw port users and cargo to the port (Martínez Moya and Feo Valero, 2017). The more efficient and cost-effective a port's operations, the better its competitive position relative to other ports that could theoretically serve the same customers (Parola et al., 2017). From this perspective, characteristics inherent to the port directly link port performance and port competitiveness. A port's performance on criteria that are important to port users steers port users in their decision to prefer one port over another and hence influences a port's competitive position relative to other ports. This article proposes a more diverse perspective on port performance and port choice, focusing on the roles of preference heterogeneity among port users, strategic behavior, stakeholder interactions, and contextual factors such as freight market conditions in explaining port choice and port competitiveness. This entails a more ambiguous conceptualization of port performance, including the idea that port choice incentives may have divergent effects on different port users and indirectly affect a port's performance in terms of cargo composition, value added, and handling efficiency.

Port performance is conceptualized as the efficiency with which companies operating in the port and port authorities are able to fulfill or facilitate and align port processes in various transport chains (Borges Vieira, Kliemann Neto and Goncalves Amaral, 2014). This paper focuses on seaborne transportation of containers, where port competition tends to be particularly fierce. Port competitiveness extends from performance and is conceptualized as a port's "capacity to provide a unique

\footnotetext{
* Corresponding author. Department of Public Administration and Sociology, Erasmus University Rotterdam, Burgemeester Oudlaan 50, 3062PA, Rotterdam, the Netherlands.

E-mail addresses: castelein@essb.eur.nl (R.B. Castelein), geerlings@essb.eur.nl (H. Geerlings), J.H.R.vanDuin@tudelft.nl (J.H.R.van Duin).
} 
value proposition under better conditions than competitors" (Parola et al., 2017: 116). A port competes with other ports that could theoretically serve the same supply chains (defined as broadly as possible, as shippers' container supply chains from the exporter's point of consolidation to the importer's location) and/or hinterland (Verhoeven, 1981; Haezendonck, 2001; Robinson, 2002). Earlier studies have discussed inter-port competition (Slack, 1985; Song, 2002; Meersman et al., 2010) and decision-making processes of the major categories of port actors: port authorities, terminals, shippers, and carriers (or shipping lines) (Heaver et al., 2001; Wiegmans et al., 2008; Talley and Ng, 2013; Martínez Moya and Feo Valero, 2017), with third party logistics providers sometimes acting as shippers' agents (Magala and Sammons, 2008; Jayaram and Tan, 2010). Other studies have provided a broader conceptualization of individual actors' choice behavior and port competitiveness (De Martino and Morvillo, 2008; Button et al., 2015). However, heterogeneity in supply chain actors' preferences and strategic behavior - and their implications - from a multi-stakeholder perspective have received relatively little attention, even though recognizing these elements provides a more comprehensive perspective on port competition and performance.

In the literature, the criteria that underpin carriers' and shippers' port choices overlap considerably (Martínez Moya and Feo Valero, 2017) and are also considered to be drivers of port competitiveness (Parola et al., 2017), but the role of possible divergence in preferences is generally overlooked. Also, strategic behavior and possible inadvertent effects resulting from port choice incentives (policy driven, physical, or a combination of the two) have received little attention. How do different actors value port choice incentives, and what are the implications for a port's competitive position?

This question is addressed by first outlining the present knowledge on port choice behavior in container transport (section 2) and combining these in a comprehensive framework (section 3). Subsequently, the paper highlights some potentially interesting interrelations that have not been addressed in the literature so far. These facets of the framework are explored further by considering the case of how the Port of Rotterdam competes with other major Western European seaports along the Hamburg-Le Havre (HLH) range. The case study draws on publicly available data on port throughput and a series of interviews conducted with a representative selection of port actors. By triangulating various sources of evidence (see section 4), the paper presents an in-depth look into how port choice incentives relate to port choice behavior and port performance and competitiveness (section 5). Section 6 discusses implications of the findings and concludes.

\section{Background - decision making in deep-sea container chains}

A container port's market share (in terms of throughput - one of the most common port performance indicators) relative to nearby competitors depends on the aggregated decisions of actors in the logistics chains that could run through the port. In deep-sea container shipping, four major categories of stakeholders are involved: port authorities, container terminals, container shipping lines (carriers), and cargo owners (shippers or their agents). This overview focuses on the deepsea part of the supply chain - hence omitting choice behavior regarding hinterland transport and short-sea shipping. The literature so far has focused on these actors' individual strategies and some interactions between two - or mostly three - actors. This study unifies these insights into one overarching framework, considering port choice incentives in the form of port policy, physical port characteristics, and freight market conditions, and their effects on different stakeholders with different preferences and strategies. Moreover, we consider several interrelations within this framework. Sub-sections 2.1-2.4 discuss insights into supply chain actors' decision making, after which section 3 presents the integrative framework connecting these.

\subsection{The shipper}

The initiator of a container supply chain is the shipper, who needs to have goods transported from one location to another and contracts service providers to organize this. A review of port choice research (Martínez Moya and Feo Valero, 2017) classifies shippers' port choice criteria into three categories: location, effectiveness, and connectivity. A port has to be suitably located relative to the origin or destination of the cargo. Of the ports that satisfy this criterion, the port that handles the cargo most efficiently (mainly in terms of costs, transit time, and reliability) and has the best connections with other ports and the hinterland will be preferred by shippers.

However, there are trade-offs that shippers consider on an individual basis, depending on their preferences. Overall, shippers aim to minimize the total logistics costs of their transport chain - monetary and otherwise (Nir et al., 2003; Talley and Ng, 2013). Faster transit often comes at a premium price, and the time that goods are in transit also imposes costs on the shipper for insurance, depreciation, restricted cash flow, and perhaps the time-sensitive nature of the cargo. Moreover, the level of service may differ between ports and logistics service providers. Depending on their preferences, shippers choose supply chain partners and ports that best suit their time, service, and cost preferences.

This is not always the shipper's decision. The party that makes the port choice is determined in the freight contract, usually along International Commercial Terms (Incoterms) rules. Here, the key distinction is between carrier haulage and merchant haulage. Under carrier haulage, the shipper chooses a container carrier, who is then responsible for the complete transport of a container (often by enlisting subcontractors for the hinterland transport) and can hence decide on the route used to transport the container, including port choice. Under merchant haulage, the shipper or consignee is responsible for arranging the land transportation and hence determines port choice. Secondly, shippers - particularly smaller companies with limited supply chain capabilities - often contract a specialized party for this. These thirdparty logistics providers (3 PL) specialize in consolidating and orchestrating supply chains, and in doing so take over decision making, such as carrier and port choice from shippers (Magala and Sammons, 2008; Jayaram and Tan, 2010). Third, a relatively new development is terminal haulage, where the terminal arranges transport to and from the hinterland (e.g. the extended gate concept (Veenstra et al., 2012)).

\subsection{The carrier}

The shipping line carries the container over sea and is usually the owner of the shipping container. Liners sail on regular routes and schedules between multiple ports and take cargo at publicly listed rates (Stopford, 2009). Shippers (or their agents) lease containers from deepsea carriers and rent capacity on container ships. Depending on the demand for transportation and port selection criteria, shipping lines adjust their planning to minimize costs and maximize volume and profits (Andersen, 2010; Meng et al., 2014).

Indirectly, shippers' port selection criteria determine carrier port selection through their effect on port-specific demand, both import and export - particularly when the goods are transported under merchant haulage. This works the other way as well, given that shippers prefer ports that are well-connected by carriers' networks. Furthermore, shipping lines have their own considerations that underpin their planning at the strategic, tactical, and operational level (Mulder and Dekker, 2017), including port selection criteria. Many of these relate to location (accessibility and berth availability), effectiveness (terminal efficiency, infrastructure quality), connectivity (deep-sea, short-sea, and hinterland connections) (Wiegmans et al., 2008; Martínez Moya and Feo Valero, 2017), and other factors including the planning of alliance partners (Panayides and Wiedmer, 2011), operational considerations such as repositioning empty containers, and subjective 
preferences (Button et al., 2015). If they have a choice between multiple terminals in a port, as is the case in most major ports, carriers also select a terminal (Wiegmans et al., 2008). This decision is chiefly driven by terminal performance criteria such as cost, capacity, accessibility, handling speed, reliability, and connectivity. Moreover, there is a role for more tacit factors such as the ease of doing business (Hupkens, 2017) and strategic factors such as carriers' long-term agreements with terminals, investments in terminals, and the terminal arrangements of alliance partners (see section 2.3). When a carrier has a position in (or a good agreement with) a terminal, this may tip the decision between two ports.

\subsection{The terminal operator}

Terminal operators handle containers at the interface between maritime and land transport, using dedicated equipment to load and unload containers from container vessels and transfer them to and from hinterland transport modalities (Lun and Cariou, 2009).

There are two distinct business models in the container handling industry. First, a company may see opportunities to profit from stevedoring activities as its core business and operate independent terminals. This is the business model of horizontally integrated global terminal operators (Slack and Frémont, 2016): these companies operate multiuser terminals that provide services to multiple shipping lines. Secondly, a shipping line may integrate vertically and operate its own terminals to cut costs and ensure capacity. Hybrid forms also exist, with terminals being joint ventures between one or multiple shipping lines and a specialized Terminal Operating Company.

Carriers not committed to a terminal in a certain port negotiate long-term agreements with multi-user terminals to reserve capacity:

Terminals commit the carrier to a minimum guaranteed volume and in exchange the carrier is usually provided with guaranteed time slots for vessel berthing and numbers of containers handled per hour. In virtually all cases, the terms of the contract are based on container moves, irrespective of size or type. There is usually a price differentiation between full and empty containers as well as a special allowance for transshipment boxes. (European Commission, 2009).

Particularly, empty containers and transshipment containers are less profitable for the terminal operator, regardless of the operational costs incurred in handling these containers.

Shipping lines define the terminal handling charge (THC) as "based on the cost of handling the container in the terminals, including loading and discharging containers to/from the vessel" (Maersk Line, 2017) - a port-specific flat-fee surcharge to the shipper. However, carriers' terminal costs are the outcome of negotiations between carriers and terminals, reflecting not only handling costs, but also the relative bargaining positions of carriers and terminals. Because these market conditions play a role in the process in which THCs are established, shippers are charged a container handling fee that is not necessarily representative of a port's true handling efficiency.

\subsection{The port authority}

Port authority policy aims to balance demands from the three main functional roles of the port: transportation node, industrial cluster, and logistics cluster (Nijdam and Van der Horst, 2017). For each function, the focus is on a different user: for the port as a transportation node, the most important users are shipping lines, but, for the port as a logistics cluster, the shipper (or 3PL) is the most important user. Naturally, the criteria are different for the different roles. For shipping lines, nautical accessibility and servicing efficiency are important, whereas for shippers, hinterland connectivity also is particularly important. However, as discussed, a port also attracts shipping lines through their attraction of shippers and their cargo.
Nowadays, European port authorities generally take a landlord role, in that they grant land concessions to terminal operators in exchange for a concession fee and additional stipulations that ensure that the broader societal goals of the port authority are also met (Notteboom and Verhoeven, 2010; Theys et al., 2010). Although a port authority aims to have terminals within the port that function as well as possible to make the port attractive for carriers and shippers, the port authority's key performance indicator is not exactly the same as for the container terminals it facilitates: whereas (multi-user) terminals strive to maximize efficiency and profits, port authorities tend to aim at maximizing throughput and revenue (Talley and $\mathrm{Ng}, 2013$ ).

Apart from concession fee revenues, port authorities charge port dues to vessels calling at the port, usually based on gross tonnage, cargo volume, or both. Port authorities can strategically adjust port dues to attract as much cargo to their ports as possible. Many ports offer discounts for transshipment cargo, second calls (i.e. a ship calling at the port twice within a few days) and volume discounts that grow incrementally as the carrier loads and/or unloads more cargo.

A framework exploring the factors underpinning these actors' decision making, their interactions, and implications for ports is elaborated in section 3 .

\section{Stakeholder choice criteria and interactions - an integrated framework}

Earlier work (Talley and Ng, 2013) noted that actors select their partners strategically, based on the criteria that they value in their supply chains. Hence, ports compete not just for cargo, but also to attract certain supply chains (Robinson, 2002). Shippers and forwarders seek to minimize their overall logistics costs and select their supply chain partners accordingly. Port authorities and terminals - despite being geographically bound - engage in the same selection behavior by negotiating long-term contracts with shipping lines (as terminals do) or long-term leases with terminals (as port authorities do). Moreover, through their pricing strategies and service offering, they attract shippers and carriers with certain preferences.

For a deeper understanding of container port competition, one should consider heterogeneity in supply chain actors' preferences. Moreover, these heterogeneous decision-making processes should be considered in relation to one another. Earlier work has highlighted interdependencies and interaction effects between supply chain actors' decision-making processes (Heaver et al., 2001; Talley and Ng, 2013; Van der Lugt, Rodrigues and Van den Berg, 2014), but a completely integrated perspective with the four key stakeholder categories, port competition, and heterogeneity in port users' preferences and requirements has been lacking. Based on the survey of choice behavior literature above, augmented with theories on competition and competitive strategies, this section presents a conceptual framework integrating these elements (Fig. 1).

The model contextualizes choice behavior (see Table 1). The supply chain choices of shippers and carriers (the most footloose port users) are considered in the broader context of a local freight market (demand for and supply of container transportation capacity, including import, export, and transshipment) and factors relating to port characteristics and policy. For the sake of parsimony, the broader context of more structural factors such as the state of the world and local economy, developments in world trade, and technology developments are considered exogenous. In aggregate, actors' contextually bound choices result in a freight market equilibrium and the respective cargo mixes and market shares of ports (i.e. their competitive position relative to other ports that compete for the same hinterland).

Market developments also influence power relations between actors, influencing the outcomes of their interactions (Parola and Musso, 2007). First, as terminals invest in capacity based on concession agreements lasting 20-30 years, supply of handling capacity is inelastic in the short and medium term once the terminal is constructed. 


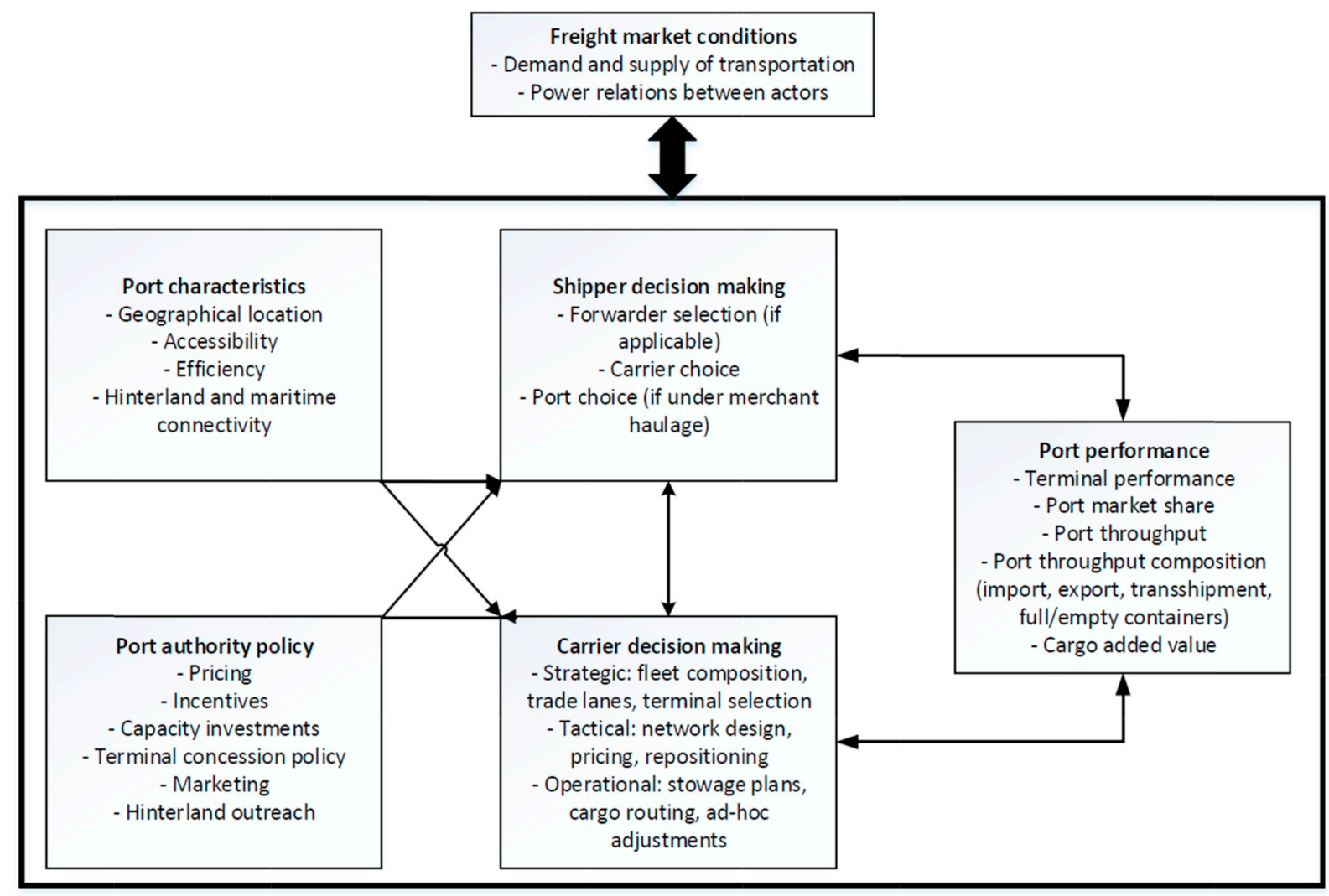

Fig. 1. Conceptual framework on port choice criteria, port user choice behavior, and implications for ports. Source: See the literature overview in Table 1.

However, demand for transportation and hence handling capacity can fluctuate strongly in a short timeframe. When demand for container transport is high and terminals are operating at full capacity, supplier power of terminal operators relative to carriers is high. However, when demand declines and there is excess capacity at terminals, supplier power of terminals diminishes. Secondly, as the liner industry consolidates and operates in closer alliances, its bargaining power vis-à-vis terminals and shippers increases (all else being equal). This can impact negatively on the performance of container terminals. For example, carriers can demand more flexibility from terminal operators, such as extended berth time or more complex handling moves at lower charges (undercutting handling efficiency), or push to renegotiate rates altogether (undercutting profitability).

Port-specific characteristics and incentives from port authority policy (of which the relevant aspects are listed in the boxes on the left side) directly influence the decision-making of shippers (consisting of forwarder, carrier, and port choice) and carriers (consisting of planning at the strategic, tactical, and operational level), as shown by unidirectional arrows. The freight market context not only influences shipper and carrier behavior, but is made up of the aggregate of their choices (hence the two-headed arrow). Port performance (in terms of market share, throughput volume and value, terminal performance, and throughput composition) is influenced by carrier and shipper choices, but is also a choice criterion for both, hence the two-directional arrows on the right side.

Discussing implications for port competition and competitiveness, we focus further on the role of port policy. Port authorities can strategically position themselves in certain transport chains to attract specific types of users. When ports in a region compete to serve the same contested hinterland, they position themselves strategically with a competitive aim. This is done through marketing policies and the incentives offered to port users. Assuming for simplicity that this positioning works along the two main choice criteria for shippers and carriers, namely, cost and service quality (broadly conceived), this positioning can be best understood using Porter's generic strategies framework (Porter, 1980). Porter describes how a company - or port can build a competitive advantage in two ways: either by having a unique advantage in the perception of customers, or by having the lowest cost in the industry. These two strategies aim at different market segments, namely, customers that value differentiated products or services versus customers for whom cost is the most important criterion. When an organization fails to be the overall cost leader, but does not deliver differentiated service to customers that value this, it becomes 'stuck in the middle', where neither the cost-sensitive customers nor the discerning high-value-oriented customers are attracted. The customers that it does attract are more footloose and are easily whisked away by organizations with low costs or a more differentiated service offer. This can be as much a matter of bad luck as the mistake of not aiming for a clearly defined strategy.

The relevance for port policy is clear if one considers trade-offs between the two major choice criteria: port service quality and costs. A low-cost port attracts supply chains that value low costs more than anything else - probably lower-value cargo that does not require specific servicing and does not generate much value added for the port. On the other hand, ports with a higher level of service quality attract the supply chains of more discerning shippers with cargo that requires more efficient handling, is perhaps more time-sensitive, or in any other way justifies higher costs for better service. This is likely to be highervalue cargo, which provides more opportunities for value added services in or related to the port cluster. Also, even if competing ports in a region all have a cost reduction focus, investments are still necessary to ensure efficiency and long-run competitiveness (Cheon et al., 2018). Ports will likely not strike the exact same balance between cost reduction and efficiency investment, resulting in differences between ports that can incentivize port user behavior analogous to price differentiation. 


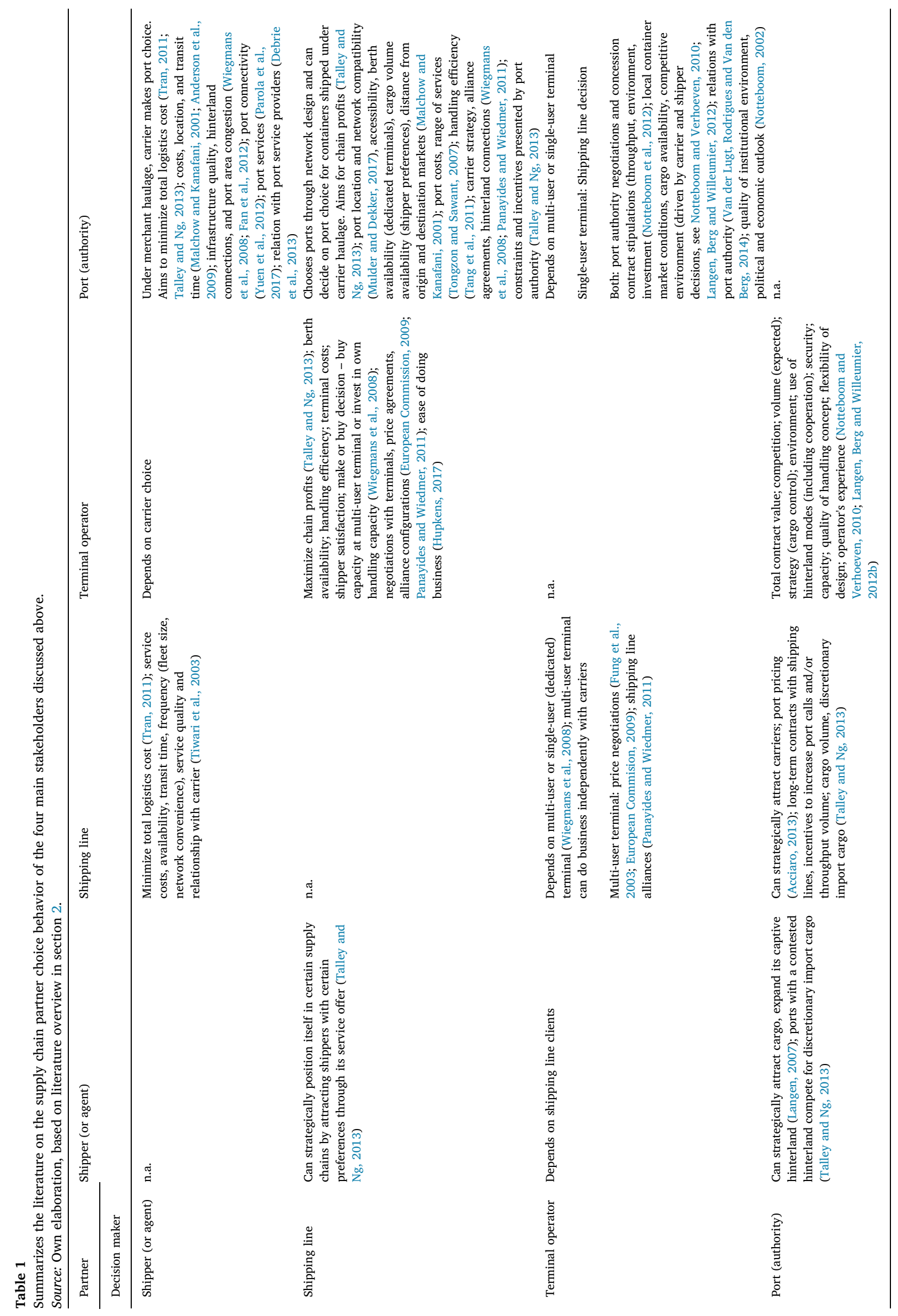


Moreover, considering the different functions of ports, and port users and their criteria, the incentive structure does not necessarily have to be the same for all users: a port that is cheapest for carriers may not be the cheapest for shippers, and the port with the best service offer for shippers may not be the best at servicing carriers.

Section 4 discusses how the interrelations inferred from the literature and presented in the model will be explored.

\section{Methodology}

Guided by existing theory on port choice behavior, section 3 outlined some plausible interdependencies referred to in passing in the literature, but not yet addressed in depth. To provide an in-depth illustration of the working of the interactions outlined in the framework, this study examines how the Port of Rotterdam competes with the other major container ports along the HLH range. The case study draws on publicly accessible information on the ports involved and their competitive positions. Secondly, industry stakeholders were interviewed. It should be noted that the nature of the data does not allow findings to be proven with statistical significance. Rather, the study "relies on multiple sources of evidence with data needing to converge in a triangular fashion" (Yin, 1994, p. 13) to achieve a rich, well-rounded narrative addressing the 'how' question of the proposed interdependencies between context, behavior, and port performance. Interviewing respondents from various types of stakeholder organizations is likely to yield contradictory perspectives on the relations of interest. However, by treating respondents as individual cases of stakeholder positions, the study aims for replication of findings following either a literal replication logic (cases with similar findings to be expected, i.e. representative of similar organizations) or a theoretical replication logic (cases with contrasting results, but for predictable reasons, i.e. representative of different types of organizations) (Yin, 1994). Combining these approaches, the case study helps to formulate a well-rounded, coherent narrative of how the relations outlined in section 3 work, which may serve as a template for theory for future work.

From October 2016 to February 2017, three representatives from the container terminal industry, three representatives of the Port of Rotterdam authority, two representatives of two major (top 10) container shipping firms, and three representatives of two major global freight forwarders were interviewed. Forwarders (as 3 PLs) were approached to elicit the shipper perspective on port choice. Many shippers are relatively small firms, making up a miniscule share of all container movements, whereas the forwarders interviewed arrange the transport of millions of containers per year for their clients. The interviewees were selected on the criterion that they should be directly involved in their firm's decision making, resulting in respondents in management positions in commercial or strategic departments. Each interview lasted between one and two hours and was conducted in a semi-structured format, with five guiding questions based on the relationships of interest discussed in section 3. This semi-structured format left room for respondents to raise relevant issues themselves, while also inviting them to share their perspectives on our conjectures. The following guiding questions were used:

1. How do you evaluate the competitive position of the Port of Rotterdam as a container port relative to nearby competitors, and what are the most important developments and their drivers?

2. How attractive is the Port of Rotterdam to carriers and shippers, and how do you see the positioning of the Port Authority and the container terminals in this market? How does this positioning/strategy compare to other ports in the region?

3. What factors are - from your perspective - most important for the competitive position of a container port?

4. Considering some aspects of Rotterdam's current competitive performance (import/export imbalance, large share of empty containers, relatively smaller call sizes), from your perspective, what are port users' considerations that could drive these trends?

5. How would you describe the relations between carriers, shippers, and terminals, and how does this relate to their chain partner choice behavior, in particular port choice?

Some respondents preferred to make statements in a personal capacity, rather than as a formal representative of their company, and therefore asked for the interviews not to be recorded. Notes were taken during the interviews and later transcribed into interview reports rather than verbatim transcripts. Hence, the statements discussed are paraphrased rather than quoted literally. Vogt et al.'s (2014: 55) handbook on research methods suggests that for the purpose of our investigation (asking "informational questions about matters of fact and interviewees' interpretations") interview notes suffice. Furthermore, to mitigate potential inaccuracies, a draft of this paper was presented to the respondents to verify whether their viewpoints were represented accurately, and whether they identified factual inaccuracies in the data or the information gathered from other interviews - of course differences in perspective between stakeholders aside. This validation round did not yield major discrepancies, suggesting that the various information sources helped highlight complementary aspects of the same phenomenon.

\section{Case outline and findings}

The relations outlined in section 3 are explored further using the case of how the Port Rotterdam competes with other ports along the HLH range.

\subsection{World trade and container shipping}

Since the crisis of 2008, the world economy has gradually recovered, but trade recovery was sluggish (OECD, 2015; IMF, 2016). This led to financial distress in the shipping sector, with excess supply and a downward pressure on freight rates. The sector's capacity to cut costs is limited in the short run, as liner companies still have to service their fixed schedules, even if demand is low (Stopford, 2009). As recently as 2016, the container shipping sector posted annual losses over $\$ 5$ billion and witnessed the bankruptcy of Hanjin Shipping, until then one of the largest carriers (Drewry, 2016). Remaining firms have pushed for consolidation to mitigate losses through scale and to improve competitiveness by expanding their market share, evidenced by several mergers and acquisitions (Wackett, 2017). Moreover, a rearrangement of the alliances in the liner market has brought the number of alliances down to three, with a number of (minor) carriers still operating independently.

This consolidation has consequences in the freight market, in that consolidation increases the buyer power of liners vis-à-vis ports and terminal operators and liners' supplier power toward shippers.

\subsection{Container port competition along the HLH range}

The ports along the HLH range handle a major share of Europe's import and export flows, and four of the world's 25 largest ports are located on this relatively short coastline.

The ports are different in overall cargo composition, but all have in common that container handling makes up an important part of their throughput. Moreover, a large share of the containers are transported under merchant haulage (on average $70 \%$ of container cargo) (Notteboom, 2008), implying that shipper decision making on port choice is highly relevant. Considering container throughput alone, the Port of Rotterdam has the largest total throughput, followed by a growing Antwerp, a recently declining Hamburg, and a somewhat smaller Bremerhaven (Fig. 2).

The ports have different physical characteristics. The Port of 


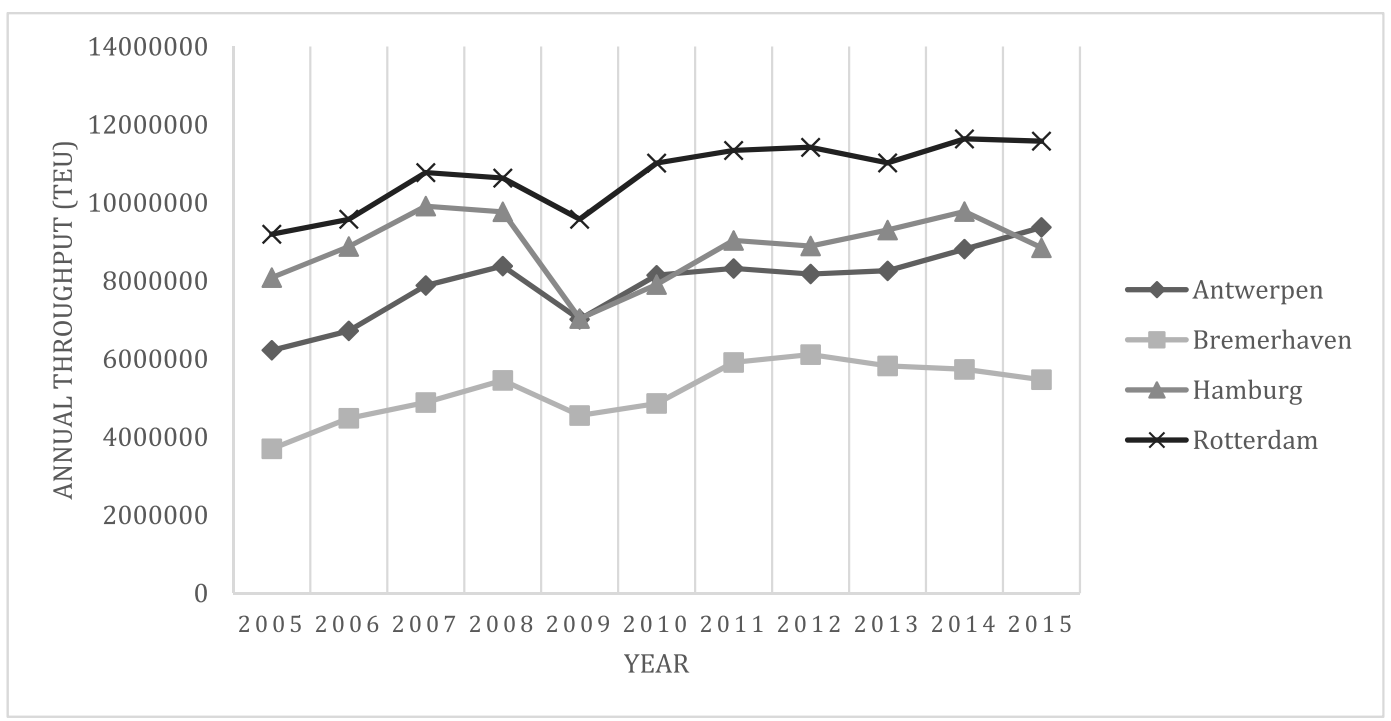

Fig. 2. Annual throughput (TEU) for four largest ports on Hamburg-Le Havre range. Source: (Eurostat, 2017a).

Table 2

Terminal handling charges of selected carriers (euros per container). Source: Corporate websites (2017).

\begin{tabular}{lllll}
\hline & Rotterdam & Antwerp & Hamburg & Bremerhaven \\
\hline Maersk & 210 & 180 & 237 & 237 \\
MSC & 205 & 190 & 220 & 220 \\
Hamburg Sud & 205 & 190 & 225 & 225 \\
Average & $\mathbf{2 0 6 . 7}$ & $\mathbf{1 8 6 . 6}$ & $\mathbf{2 2 7 . 3}$ & $\mathbf{2 2 7 . 3}$
\end{tabular}

Antwerp lies upstream along the Scheldt, posing constraints on the port's accessibility: the newest container vessels of 20,000 TEU and over cannot enter the port fully loaded because of depth restrictions. In the Port of Rotterdam, the Tweede Maasvlakte has been created to expand the port's container handling capacity. This new extension is easily accessible from sea by ships of all sizes. The container terminals in Rotterdam - particularly those at the newly constructed Tweede Maasvlakte - are considered to be state-of-the-art (Langen, Berg and Willeumier, 2012a). However, with the opening of the Tweede Maasvlakte in 2013, more capacity became available than was demanded in that generally depressed freight market. In Bremerhaven, the four deep-sea container terminals, all located on one stretch of $5 \mathrm{~km}$-long quay, are easily accessible for deep-sea vessels. However, as the current quay stretches to the city-state limit, further port expansion is unlikely. Lastly, the Port of Hamburg lies along the Elbe, some $80 \mathrm{~km}$ inland from the sea. Because of the draft restrictions imposed by the Elbe, the port cannot accommodate the largest container vessels fully loaded.

\subsection{Pricing and throughput composition}

Section 5.2 shows that the ports differ considerably on physical indicators of port competitiveness, i.e. geographical location and accessibility. Whereas Rotterdam and Bremerhaven are easily accessible for deep-sea ships, Antwerp and Hamburg cannot be accessed by the largest container ships fully loaded because of draft restrictions.

In terms of the port choice framework distilled from the literature, this section (5.3) surveys all relevant findings on port choice incentives (port characteristics and policy) and port performance for the four major HLH ports. Given that important performance indicators are the result of the aggregate of shipper and carrier decision making, two specific interrelations are explored further. First, section 5.4.1 draws on interview findings to explore how port choice incentives impact upon actor choice behavior and in turn on performance. Secondly, section 5.4.2 explores how freight market conditions and power relations impact on decision makers' incentives, choice behavior, and ultimately port performance.

To shippers, a port is priced through the THCs (Terminal Handling Cost) listed by carriers. These are the same in both directions: i.e. a container shipped from Hamburg to anywhere in the world has the same handling charge as a container shipped from anywhere to Hamburg.

Antwerp tends to be the cheapest, the German ports are most expensive, and Rotterdam is in between (Table 2). These THCs charged to shippers likely deviate from the costs incurred by the terminal and carriers, and from the rates negotiated between carriers and terminals in the scenario where this is negotiated with an independent terminal, rather than a dedicated terminal simply operating as a cost center for a carrier. However, as these are the rates offered to shippers, they likely have a real effect on port choice.

The cost structure of carriers is composed of several factors apart from the handling rates negotiated with terminals, including port dues, quay, buoy, and dolphin dues, mooring services, and tugs and pilotage. An inventory made by the Port of Rotterdam Authority shows that, in terms of total call costs, Rotterdam is the cheapest, followed by Bremerhaven, Antwerp, and Hamburg, respectively (personal communication, 2017).

Another part of the pricing structure faced by carriers is the incentives that port authorities offer to attract port calls and volume. The most common incentives are discounts for vessels calling twice on the same leg of a route, discounts for transshipment containers, and volume discounts. Table 3 shows that Rotterdam offers the most generous price incentives - at least in a comparison based on those listed publicly on port authorities' websites and publicly available documents.

Considering the cargo composition beyond volume alone, we examine publicly available data on the direction and content (full or empty) of container flows through the major HLH ports. Fig. 3 shows the balance between incoming and outgoing container flows, and Fig. 4 the share of empty containers in total outgoing container flows.

This warrants two observations. First, in Rotterdam the balance between incoming and outgoing containers has become more skewed since 2009. In 2015, for every 10 containers coming in, a little over eight - on average - were exported. To illustrate: 10 containers are imported by firms in the European hinterland, but for all that is 
Table 3

Port dues discounts for four major ports.

Source: Corporate websites, most recent versions of tariff specifications (2017).

\begin{tabular}{llll}
\hline Port & Second call discount (per call) & Transshipment discount (per container) & Quantity discount (per call, based on total annual volume of carrier) \\
\hline Antwerp & $50 \%$ & n.a. & n.a. \\
Rotterdam & $75 \%$ & $€ 5.00$ & Up to $22 \%$ \\
Bremerhaven & $50 \%$ & n.a. & n.a. \\
Hamburg & $50 \%$ & Up to $€ 0.50$ & n.a. \\
\hline
\end{tabular}

imported and processed, only eight containers of goods leave. Twenty percent of containers 'disappear,' to reappear in the ports that serve the same hinterland, but have a positive export/import balance, such as Bremerhaven and Antwerp. In the long run, this may not be a good sign for a port, as it indicates that it is relatively less attractive to exporting shippers in its own hinterland.

A second observation relates to the share of empty containers. Empty containers are transported through a port at the discretion of the carrier, so a larger share of empty containers indicates that a port is relatively more attractive for carriers to do their repositioning. These are, however, less valuable cargo, relatively less profitable for container terminals to handle - as discussed in relation to the fixing of the THCs between terminals and carriers - and indicate that a port may be transporting less value than throughput statistics alone may suggest. Antwerp, Bremerhaven, and Hamburg have gradually reduced the share of empty containers exported, but in Rotterdam one in every five containers exported is empty. These trends suggest that, despite a stable throughput, the competitive position of the Port of Rotterdam warrants two critical remarks: A lot more cargo is imported than is exported through the port, and a large number of the containers that go out are empty.

Combining container throughput data with data on container vessel calls results in Fig. 5.

As the average vessel size increases, one would expect the number of containers loaded and unloaded per call (the call size) to increase as well. This is visible for all ports (with the possible exception of Bremerhaven), but Rotterdam has started lagging behind in terms of call size relative to Antwerp and Hamburg - two ports in which one would expect it to a lesser degree given their draft restrictions. Assuming that the same liner vessels call on the major HLH ports, container terminals in Rotterdam are handling relatively fewer containers per call on the same trades than the ports with which it was on par some years ago. Given that container terminals incur costs for each call (idle time of quayside resources while the ship is mooring or leaving and any window of time that the ship may be arriving early or late), this hurts the efficiency of the Rotterdam container terminals.

Last, in terms of port efficiency, on the World Bank 'Quality of Port Infrastructure' indicator, the Netherlands scores 6.8, Belgium 6.3, and Germany 5.6 (World Bank, 2016). Assuming that the largest ports are highly representative of a country's overall port infrastructure quality, these figures suffice as a rough proxy measure of the focal ports' infrastructure quality.

The data surveyed warrant several observations. First, the price structure facing shippers does not necessarily correspond with the price structure facing carriers: the cheapest port from the perspective of a carrier (based on port costs) is not the cheapest from the perspective of a shipper (based on port-specific THCs). Second, the cheapest and one of the most accessible ports for carriers with the best infrastructure Rotterdam - does not attract the best business: relatively few containers per vessel call, a sharp import/export imbalance, and a large share of empty container movements.

\subsection{Interview findings}

This section draws on observations from the interviews conducted to contextualize the observations made above.

\subsubsection{Port choice incentives}

The major HLH range ports compete to a large extent for the same hinterland. Shippers and carriers make their port choice based on their own preferences and the ports' price/quality offer. Through the incentive mechanisms consisting of port characteristics and port policy, ports attract clients with certain preferences and over time develop a certain profile of certain types of users and activities.

Per port, different incentive structures for shippers and carriers, and different stakeholders' policies, can be distinguished. Antwerp offers the lowest THCs, German THCs are relatively high, and Rotterdam is in between but differentiates itself by offering greater incentives to

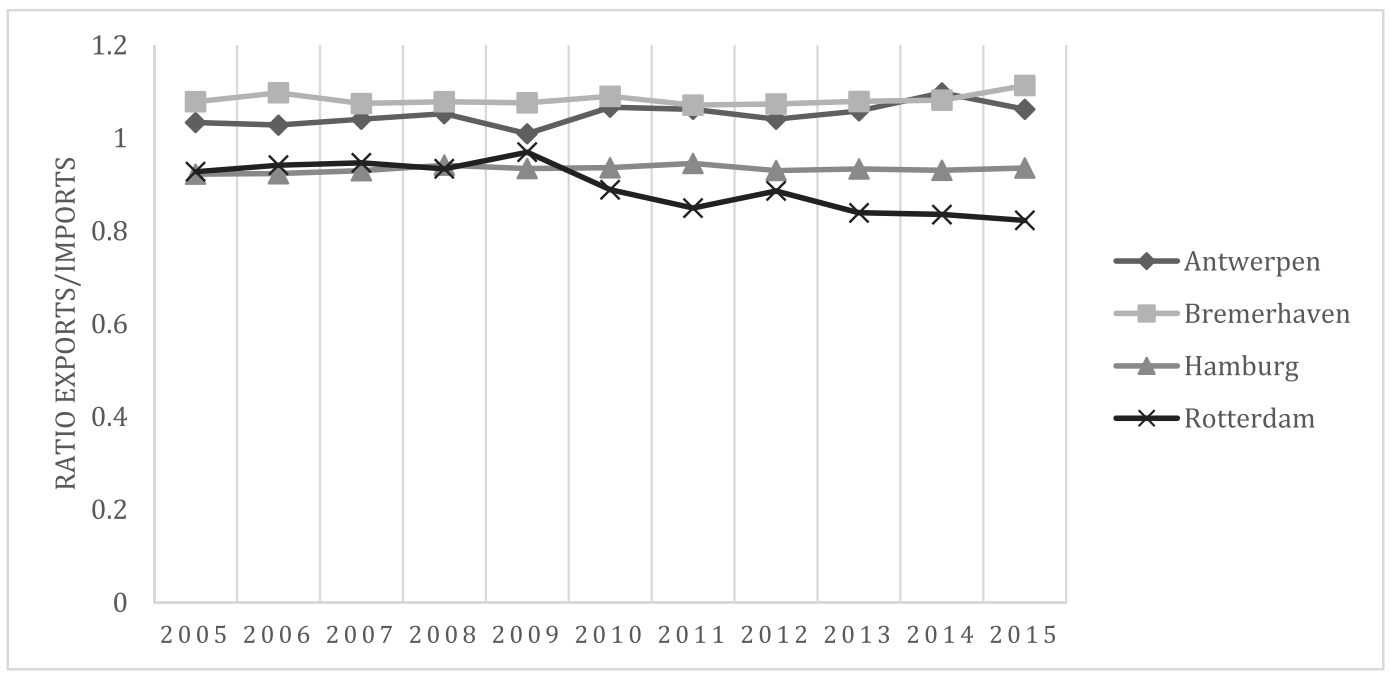

Fig. 3. Balance between incoming and outgoing containers (in TEU).

Source: (Eurostat, 2017b). 


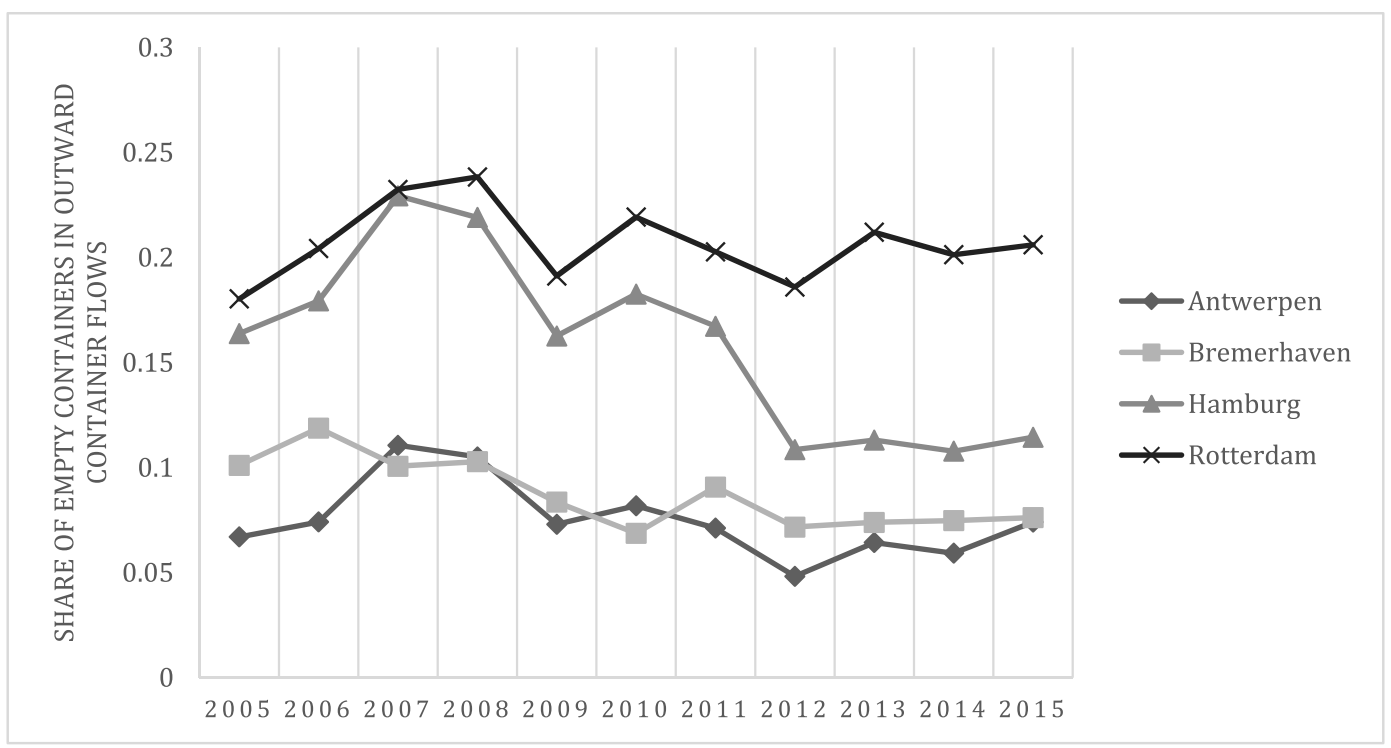

Fig. 4. Share of empty containers in outgoing container flows (TEU).

Source: (Eurostat, 2017b).

carriers than other ports do. However, the interviewees made some remarks with regard to these numbers. One forwarder emphasized that large German shippers have long-term agreements with carriers, with lower THCs than those quoted publicly. A port authority representative affirmed this and estimated that the difference in effective THCs between Rotterdam and the German ports has diminished. Unequivocally, the interviewees agreed that Antwerp is the cost leader along the HLH range. The terminals, equipment, and infrastructure are not state-ofthe-art, but costs are kept low for price-sensitive shippers. Carrier MSC uses Antwerp as a home port, focusing on low costs and high volumes, and various interviewees estimated that the throughput growth in Antwerp resulted mainly from MSC cargo.

The Port of Rotterdam distinguishes itself by offering the most generous port dues discounts, but this comes with some caveats. One carrier representative acknowledged that the Port of Rotterdam was more public about its discounts but mentioned that, in all ports, discount deals are made regularly with carriers. Another carrier representative was particularly appreciative of the "aggressive" discounts offered by the Port of Rotterdam relative to other ports. All interviewees affirmed that, in terms of total call costs (port dues, including discounts, pilotage, tugs, quay dues), Rotterdam is the cheapest of the
HLH ports for carriers - along with the geographical advantages of its location, its efficient infrastructure, and terminals that work around the clock. One forwarder noted that these cost advantages accrue primarily to carriers: shippers are quoted the THCs as listed and make their port choices accordingly.

Terminal representatives noted that terminals' cargo profiles differ considerably. Apparently, Rotterdam attracts a disproportionate share of empty containers, transshipment cargo, and repositioning requests from carriers. This is ascribed to a combination of factors, namely, the ease of access to Rotterdam, the handling efficiency of the terminals, and the overall low costs of port calls. Carriers reposition empty containers at their own cost, so they prefer to move these through the port with the lowest costs and the most efficient infrastructure. One carrier representative affirmed that Rotterdam has always attracted a large share of empty containers and transshipment cargo through its geographical position and relatively low costs for carriers.

Apart from cargo composition, ports' shipper profiles differ. One forwarder illustrated how Hamburg and Antwerp have relatively large shares of carrier haulage, whereas Rotterdam has a larger share of merchant haulage. Carriers earn more on carrier haulage, whereas shippers using merchant haulage tend to have greater demands on

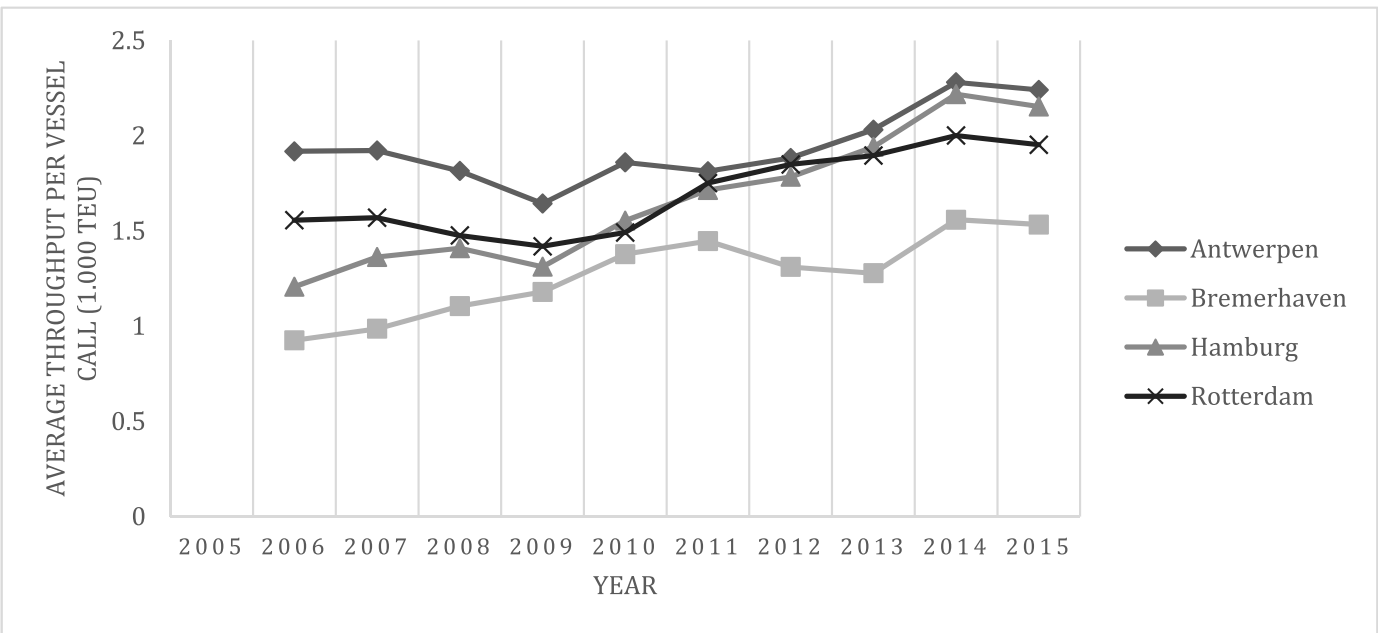

Fig. 5. Average throughput (1000 TEU) per vessel call per year 2005-2015.

Source: (Eurostat, 2017a). 
service quality and handling speed, as well as a cost focus. Hence, between ports, the client profile and demand factors differ considerably.

Total logistics costs - of which the THC is a component - are an important criterion for shippers' port choice. However, other preferences are also relevant. All carriers, terminal operators, and forwarders noted that German clients tend to be somewhat "chauvinistic" in their choices and prefer doing business with someone who speaks their language (literally and figuratively) and therefore are oriented predominantly toward German partners and German ports. Carrier and terminal representatives stated that port authorities do not recognize this dimension of port choice enough. This cultural component is also visible in Antwerp and Rotterdam, according to forwarder representatives. Clients of the Port of Antwerp tend to ship lower-value cargoes and are more tolerant of hold-ups and longer transit times, as long as this reduces costs (a "very Belgian attitude" according to one forwarder). Clients with Rotterdam-oriented supply chains tend to ship higher-value cargoes, and expect both low costs and high-quality service. These clients tend to be footloose and willing to shift their cargo to another port - either to the cost leader or to parties that they feel offer preferred services at an acceptable premium - if they feel that a port underperforms.

This seems indicative of a pattern along Porter's generic strategies, but not the same for carriers and shippers alike. Concerning shippers, THCs and service differentiation in a port can make a difference. To a predominantly German hinterland, German-port-oriented supply chains offer services for which shippers are willing to pay. Antwerp is a cost leader, whereas Rotterdam attracts shippers with both cost-driven and quality-driven preferences. This is seemingly a more footloose segment than those focusing only on cost or those willing to pay a premium for service regardless. Concerning carriers, the incentives work differently. Apart from attracting shippers' cargo, ports can attract carriers by being accessible and (cost-)efficient. Rotterdam's geographical characteristics make it attractive to carriers, who can enter with fully loaded container ships at any time. Accordingly, Rotterdam is usually the first port of call for lines deploying the largest container ships and the preferred port for import cargo (shipper's choice), transshipment, and repositioning (liner's choices).

\subsubsection{Freight market conditions and strategic behavior}

The interviewees affirmed that market conditions, through their effects on power relations between supply chain stakeholders, have indirect effects on port and terminal performance. One carrier representative stated that

When the market was booming, carriers were worried that they would not be able to secure terminal capacity in HLH ports, so many invested in positions in deep-sea terminals. When there is overcapacity in ports, carriers have more leverage in negotiations with terminals. For carriers, excess capacity and competition between terminals are convenient, as they allow them to push rates down. In a sense, carriers play out competition between terminals.

Various respondents noted that carriers have their choice of multiuser terminals in Rotterdam - as these terminals nearly all have excess capacity - and can demand concessions regarding price, guarantees, and service. A Port Authority representative expected this intensified competition to be temporary:

With the Tweede Maasvlakte and developments in the liner market, the terminal market in Rotterdam has been disrupted, and it is still being settled who serves which clients. This has intensified competition, but once the market settles back into equilibrium and terminals are fully operational, relations and cooperation will go back to normal.

In this context of relatively high buyer power, liner planning affects port and terminal performance. The number of containers handled per call has stagnated in Rotterdam - even though the vessel size increases continue to be reflected in the figures for the other HLH ports - and the share of empty containers is particularly high. Some respondents attribute this to liner companies' planning.

A stylized example: As Rotterdam can be entered fully loaded, this is usually the first port of call on the major lanes. This first call is used to discharge import cargo and reposition containers on the ship, as the containers are usually stacked as low and as flat as possible to minimize the container tiers-based toll at the Suez Canal, but this does not make for the most efficient stowage plan to call on multiple ports. Subsequently, the ship sails on with enough draft reduction to access Antwerp and/or Hamburg. Before leaving Europe again, Rotterdam is called on once more to collect the last export shipments and some last repositioning. For carriers, this second call is cheap, because of considerable discounts and overall relatively low call costs. However, this routing is unfortunate for the terminals in Rotterdam: Import and export cargo is split between two separate, but overall less efficient, calls. Also, the first call involves some repositioning on the ship, but these are not profitable moves for a container terminal as no container is loaded or unloaded. One terminal representative estimated that, per call, at most one hundred repositioning moves take place, but with moves between different bays of the ship, they entail inefficient use of equipment.

The implications of carrier planning for port and terminal performance extend beyond these first and last port of call issues. A forwarder mentioned an increase in 'cut and run' calls in Rotterdam, where a ship leaves a port before the loading and unloading is finished, in order to be at another port in time (either to benefit from a high tide or to meet a time window at the next terminal). When consequently containers have to be rerouted, shippers pay the price. If they experience problems like this often, they will consider routing their containers through another port. The same forwarder noted that carrier schedules generally have become more erratic and port calls in Rotterdam less punctual, causing uncertainty for the port's terminals and shippers. In this case, carriers use the most easily accessible and most efficient port to pick up the slack in their operational planning.

\section{Discussion and conclusions}

The findings reveal an interesting paradox. For carriers, Rotterdam is the cheapest and most convenient port, but these benefits are not reflected in shippers' incentives. In fact, the price structure along the HLH range may even leave Rotterdam 'stuck in the middle' - between cost leader Antwerp and German ports that seem to naturally attract cargo from the German hinterland - with a demanding and footloose clientele of shippers. While carriers' relative market power is high, Rotterdam's good geographical position may even be disadvantageous, as carriers use the cheapest and most convenient port for relatively lowvalue activities and activities that make less efficient use of terminals. These include moving empty containers and strategies to compensate for restrictions imposed by other ports, such as on-ship repositioning, ad-hoc schedule changes, and double calls.

The findings from the case are obviously specific to the situation of Rotterdam and the HLH range, but some general considerations for port policy can be offered by considering the behavioral mechanisms highlighted. In particular, a twofold challenge for port policy can be identified: First, ports that are attractive to carriers are not necessarily equally good at appealing to shippers, inviting a question relating to how incentives to attract shippers to opt for the port can become better aligned with incentives to attract carriers. Secondly, when a port is relatively more attractive to carriers, a larger share of its handling activity and throughput consists of relatively low-value activities (e.g. repositioning, empty container transport, inefficient calls). Apparently, translating or extending the properties of the port that attract carriers into properties that attract shippers remains a challenge. How can a port's physical advantages - location, infrastructure, equipment, etc. and competitive pricing that attract carriers also help to attract valuable 
cargo and value-adding activity to the port?

These considerations come with some caveats. Although we assume that shippers make decisions in their capacity as cargo owner, and carriers make decisions in their capacity as deep-sea liner operator, there are likely cases in which these distinctions may blur. An example would be a container shipped under carrier haulage. However, as in Western Europe the majority of cargo is shipped under merchant haulage, shipper decision making can be expected to be a major factor, separate from carrier planning. Another limitation of this study is that the mechanisms described cannot be proven with statistical significance. Instead, we triangulate evidence from various quantitative and qualitative sources to provide a plausible behavioral explanation for observed phenomena. The rich information gathered from individual interviews and quantitative data on port throughput did not produce factual contradictions, but in fact highlight complementary aspects of the interdependency of port users' decision making, suggesting that the findings could serve to deepen theoretical perspectives on interrelations and complexities between port actors' choice behaviors.

Generally, the findings present interesting theoretical questions for future research. So far, port choice criteria have been assumed to be roughly similar for carriers and shippers, but we have shown that their effects on choice behavior and implications for ports can diverge substantially, with unexpected implications such as those highlighted in this paper. Therefore, it is desirable to elucidate systematically when and under what conditions which port characteristics and policy attract which actors with what type of cargo and activity to the port. This extends further to the question how container flows contribute to value creation in ports. Some containers travel long distances to and from the port without being opened, but, for other cargoes, consolidation and deconsolidation activities - and perhaps even other activities such as packaging, assembly, or production - may be concentrated in the port cluster. The question remains how ports can attract more high-value cargoes and activities to the port cluster.

\section{Funding acknowledgement}

The authors are working in research project EURECA (Effective Use of Reefer Containers Through the Port of Rotterdam - A Transition Oriented Approach), with project number 438-15-505, which is partly funded by the Netherlands Organization for Scientific Research (NWO).

\section{$\widehat{N \mathcal{W}} \begin{aligned} & \begin{array}{l}\text { Netherlands Organisation } \\ \text { for Scientific Research }\end{array} \\ & \text { for }\end{aligned}$}

\section{Acknowledgements}

We would like to thank our respondents for their time in conducting the interviews and for their helpful comments on earlier drafts of this paper. Furthermore, we would like to thank the two anonymous reviewers of Transport Policy for their extensive comments on earlier versions of this paper.

\section{Appendix A. Supplementary data}

Supplementary data related to this article can be found at https:// doi.org/10.1016/j.tranpol.2019.04.010.

\section{References}

Acciaro, M., 2013. A critical review of port pricing literature: what role for academic research? Asian Journal of Shipping and Logistics 29 (2), 207-228. https://doi.org/ 10.1016/j.ajsl.2013.08.005.

Andersen, M.W., 2010. Service Network Design and Management in Liner Container Shipping Applications. Technical University of Denmark. http://www.aaben.dtu.dk/ upload/institutter/dtu transport/rapporter/thesis.pdf.

Anderson, C.M., Opaluch, J.J., Grigalunas, T.A., 2009. The demand for import services at
US container ports. Marit. Econ. Logist. 11 (2), 156-185. https://doi.org/10.1057/ mel.2009.4.

Borges Vieira, G.B., Kliemann Neto, F.J., Goncalves Amaral, F., 2014. Governanc, governance models and port performance: a systematic review. Transport Rev. 34 (6), 645-662. https://doi.org/10.1080/01441647.2014.946458.

Button, K., Chin, A., Kramberger, T., 2015. 'Incorporating subjective elements into liners' seaport choice assessments'. Transport Pol. 44, 125-133. https://doi.org/10.1016/j. tranpol.2015.07.006.

Cheon, S., Song, D.-W., Park, S., 2018. Does more competition result in better port performance ? Maritime Economics \& Logistics. Palgrave Macmillan UK 20 (3), 433-455. https://doi.org/10.1057/s41278-017-0066-8.

Debrie, J., Lavaud-Letilleul, V., Parola, F., 2013. Shaping port governance: the territorial trajectories of reform. J. Transp. Geogr. Elsevier Ltd 27, 56-65. https://doi.org/10. 1016/j.jtrangeo.2012.07.007.

Drewry, 2016. Container shipping market has bottomed out. https://www.drewry.co.uk/ news/container-shipping-market-has-bottomed-out.

European Commission, 2009. Terminal Handling charges during and after the liner conference era. Publications Office of the European Union, Luxembourg.

Eurostat, 2017a. Database; various tables. http://ec.europa.eu/eurostat/data/database, Accessed date: 29 November 2017.

Eurostat, 2017b. Database; Various Tables.

Fan, L., Wilson, W.W., Dahl, B., 2012. Congestion, port expansion and spatial competition for US container imports. Transport. Res. E. Elsevier Ltd 48 (6), 1121-1136. https:// doi.org/10.1016/j.tre.2012.04.006.

Fung, M.K., Cheng, L.K., Qiu, L.D., 2003. The impact of terminal handling charges on overall shipping charges: an empirical study. Transport. Res. Part A 37, 703-716. https://doi.org/10.1016/S0965-8564(03)00026-0.

Haezendonck, E., 2001. Essays on Strategy Analysis for Seaports. Garant Publishers, Louvain.

Heaver, T.D., Meersman, H., Van de Voorde, E., 2001. Co-operation and competition in international container transport: strategies for ports. Marit. Pol. Manag. 28 (3), 293-305. https://doi.org/10.1080/03088830110055693.

Hupkens, M., 2017. Terminalkeuze Van Deep-Sea Rederijen. Delft University of Technology.

IMF, 2016. World Economic Outlook April 2016. Washington.

Jayaram, J., Tan, K., 2010. Supply chain integration with third-party logistics providers. Int. J. Prod. Econ. Elsevier 125, 262-271. https://doi.org/10.1016/j.ijpe.2010.02 014.

Langen, P. W. De, 2007. Port competition and selection in contestable hinterlands; the case of Austria. Eur. J. Transp. Infrastruct. Res. 7 (1), 1-14.

Langen, P. W. De, Berg, R. Van Den, Willeumier, A., 2012a. 'A new approach to granting terminal concessions : the case of the Rotterdam World Gateway terminal'. Marit. Pol. Manag. 29 (1), 79-90. https://doi.org/10.1080/03088839.2011.642311.

Langen, P. W. De, Berg, R. Van Den, Willeumier, A., 2012b. A new approach to granting terminal concessions: the case of the Rotterdam World Gateway terminal. Marit. Pol. Manag. 29 (1), 79-90. https://doi.org/10.1080/03088839.2011.642311.

Van der Lugt, L.M., Rodrigues, S.B., Van den Berg, R., 2014. Co-evolution of the strategic reorientation of port actors: insights from the port of Rotterdam and the port of barcelona. J. Transport. Geogr. Elsevier Ltd, vol. 41, 197-209. https://doi.org/10 1016/j.jtrangeo.2014.09.008.

Lun, Y.H.V., Cariou, P., 2009. An analytical framework for managing container terminals Int. J. Shipp. Transp. Logist. (IJSTL) 1 (4), 419-436. https://doi.org/10.1504/IJSTL. 2009.027683.

Maersk Line, 2017. Freight shipping rates and container costs. Available at: http://wcmorigin.maerskline.com/en-sl/shipping-services/rates-and-pricing, Accessed date: 17 August 2017.

Magala, M., Sammons, A., 2008. A new approach to port choice modelling. Marit. Econ. Logist. 10 (1-2), 9-34. https://doi.org/10.1057/palgrave.mel.9100189.

Malchow, M., Kanafani, A., 2001. A disaggregate analysis of factors influencing port selection. Marit. Pol. Manag. 28 (3), 265-277. https://doi.org/10.1080/ 03088830110060840.

Martínez Moya, J., Feo Valero, M., 2017. Port choice in container market: a literature review. Transport. Rev. Taylor \& Francis 37 (3), 300-321. https://doi.org/10.1080/ 01441647.2016.1231233.

De Martino, M., Morvillo, A., 2008. Activities , resources and inter-organizational relationships: key factors in port competitiveness. Marit. Pol. Manag. 35 (6), 571-589. https://doi.org/10.1080/03088830802469477.

Meersman, H., Voorde, E. Van De, Vanelslander, T., 2010. Port competition revisited. Rev. Bus. Econ. Lit. 55 (2), 210-233.

Meng, Q., et al., 2014. Containership routing and scheduling in liner shipping: overview and future research directions. Transport. Sci. 48 (2), 265-280. https://doi.org/10. $1287 /$ trsc. 2013.0461.

Mulder, J., Dekker, R., 2017. Optimisation in container liner shipping. In: Geerlings, H., Kuipers, B., Zuidwijk, R. (Eds.), Ports and Networks. Strategies, Operations, and Perspectives. Routledge, London and New York, pp. 181-203.

Nijdam, M., Van der Horst, M., 2017. Port definition, concepts and the role of ports in supply chains. In: Geerlings, H., Kuipers, B., Zuidwijk, R. (Eds.), Ports and Networks. Strategies, Operations, and Perspectives. Routledge, London, New York, pp. 9-25.

Nir, A.-S., Lin, K., Liang, G.-S., 2003. Port choice behaviour-from the perspective of the shipper. Marit. Pol. Manag. 30 (2), 165-173. https://doi.org/10.1080/ 0308883032000069262.

Notteboom, T., 2002. Consolidation and contestability in the European container handling industry. Marit. Pol. Manag. 29 (3), 257-269. https://doi.org/10.1080/ 03088830210132614.

Notteboom, T., 2008. Bundling of freight flows and hinterland network developments. In: Konings, R., Priemus, H., Nijkamp, P. (Eds.), The Future of Intermodal Freight 
Transport: Operations, Design and Policy. Cheltenham \& Northampton: Edward Elgar, pp. 66-88.

Notteboom, T.E., Pallis, A.A., Farrell, S., 2012. Terminal concessions in seaports revisited. Marit. Pol. Manag. 39 (1), 1-5. https://doi.org/10.1080/03088839.2012.644476.

Notteboom, T., Verhoeven, P., 2010. The awarding of seaport terminals to private operators: current practices and viewpoints in European ports. European Transport 45, 83-101. Available at: papers3://publication/uuid/BC8DC795-5853-4E83-A6CAD0CC0C9854EC.

OECD, 2015. OECD Economic Outlook Vol 2015 Issue 2. Paris. https://doi.org/10.1787/ eco_outlook-v2015-1-en.

Panayides, P.M., Wiedmer, R., 2011. Strategic alliances in container liner shipping. Research in Transportation Economics. Elsevier Ltd 32 (1), 25-38. https://doi.org/ 10.1016/j.retrec.2011.06.008.

Parola, F., et al., 2017. The drivers of port competitiveness: a critical review. Transport. Rev. Taylor \& Francis 37 (1), 116-138. https://doi.org/10.1080/01441647.2016. 1231232.

Parola, F., Musso, E., 2007. Market structures and competitive strategies: the carrier stevedore arm-wrestling in northern European ports. Marit. Pol. Manag. 34 (4), 259-278. https://doi.org/10.1080/03088830701343369.

Porter, M.E., 1980. Competitive Strategy. Free Press, New York.

Robinson, R., 2002. Ports as elements in value-driven chain systems: the new paradigm. Marit. Pol. Manag. 29 (3), 241-255. https://doi.org/10.1080/03088830210132623.

Slack, B., 1985. Containerization, inter-port competition, and port selection. Marit. Pol Manag. 12 (4), 293-303. https://doi.org/10.1080/03088838500000043.

Slack, B., Frémont, A., 2016. 'Transformation of port terminal operations : from the local to the global'. Transport Rev. 25 (1), 117-130. https://doi.org/10.1080/ 0144164042000206051.

Song, D.-W., 2002. Regional container port competition and co-operation: the case of Hong Kong and South China. J. Transp. Geogr. 10 (2), 99-110. https://doi.org/10. 1016/S0966-6923(02)00003-0.

Stopford, M., 2009. Maritime Economics, third ed. Routledge, London and New York.

Talley, W.K., Ng, M., 2013. Maritime transport chain choice by carriers, ports and shippers. Int. J. Prod. Econ.. Elsevier 142 (2), 311-316. https://doi.org/10.1016/j. ijpe.2012.11.013.

Tang, L.C., Low, J.M.W., Lam, S.W., 2011. Understanding port choice behaviour: a network perspective. Network. Spatial Econ. 11 (1), 65-82. https://doi.org/10.1007/ s11067-008-9081-8.

Theys, C., et al., 2010. The economics behind the awarding of terminals in seaports: towards a research agenda. Research in Transportation Economics. Elsevier Ltd 27 (1), 37-50. https://doi.org/10.1016/j.retrec.2009.12.006.

Tiwari, P., Itoh, H., Doi, M., 2003. 'Shippers' port and carrier selection behaviour in China: a discrete choice analysis'. Marit. Econ. Logist. 5 (1), 23-39.

Tongzon, J.L., Sawant, L., 2007. Port choice in a competitive environment: from the shipping lines' perspective. Appl. Econ. 39 (4), 477-492. https://doi.org/10.1080/ 00036840500438871.

Tran, N.K., 2011. Research in Transportation Economics Studying port selection on liner routes: an approach from logistics perspective. Research in Transportation Economics. Elsevier Ltd 32 (1), 39-53. https://doi.org/10.1016/j.retrec.2011.06. 005.

Veenstra, A., Zuidwijk, R., van Asperen, E., 2012. The extended gate concept for container terminals: expanding the notion of dry ports. Marit. Pol. Manag. 14, 14-32. https:// doi.org/10.1057/mel.2011.15.

Verhoeven, P., 1981. Seaport competition: some fundamental and political aspects. Marit. Pol. Manag. 8 (1), 49-60.

Vogt, W.P., et al., 2014. Selecting the Right Analyses for Your data. Quantitative, Qualitative, and Mixed Methods. The Guilford Press, London, New York.

Wackett, M., 2017. More container shipping M\&A activity expected as smaller carriers try to keep up. The Loadstar Available at: https://theloadstar.co.uk/container-shippingma-activity-expected-smaller-carriers-try-keep/.

Wiegmans, B.W., Hoest, A. Van Der, Notteboom, T.E., 2008. Port and terminal selection by deep-sea container operators. Marit. Pol. Manag. 35 (6), 517-534. https://doi. org/10.1080/03088830802469329.

World Bank, 2016. Quality of port infrastructure. Available at: https://data.worldbank. org/indicator/IQ.WEF.PORT.XQ, Accessed date: 29 September 2017.

Yin, R.K., 1994. Case Study Research. Design and Methods (Second edition), second ed. Sage Publications, Thousand Oaks, London, New Delhi.

Yuen, C.L.A., Zhang, A., Cheung, W., 2012. Port competitiveness from the users' perspective: an analysis of major container ports in China and its neighboring countries. Res. Transport. Econ. Elsevier Ltd 35 (1), 34-40. https://doi.org/10.1016/j.retrec. 2011.11.005. 